\title{
Aneurysmal subarachnoid hemorrhage: intensive care for improving neurological outcome
}

\author{
Tomoya Okazaki ${ }^{*}$ and Yasuhiro Kuroda ${ }^{2}$
}

\begin{abstract}
Background: Aneurysmal subarachnoid hemorrhage is a life-threatening disease requiring neurocritical care. Delayed cerebral ischemia is a well-known complication that contributes to unfavorable neurological outcomes. Cerebral vasospasm has been thought to be the main cause of delayed cerebral ischemia, and although several studies were able to decrease cerebral vasospasm, none showed improved neurological outcomes. Our target is not cerebral vasospasm but improving neurological outcomes. The purpose of this review is to discuss what intensivists should know and can do to improve clinical outcomes in subarachnoid hemorrhage patients.

Main body of the abstract: Delayed cerebral ischemia is thought to be due to not only vasospasm but also multifactorial mechanisms. Additionally, the concept of early brain injury, which occurs within the first $72 \mathrm{~h}$ after the hemorrhage, has become an important concern. Increasing sympathetic activity after the hemorrhage is associated with cardiopulmonary complications and poor outcomes. Serum lactate measurement may be a valuable marker reflecting the severity of sympathetic activity. The transpulmonary thermodilution method will bring about an advanced understanding of hemodynamic management. Fever is a well-recognized symptom and targeted temperature management is an anticipated intervention. To avoid hyperglycemia and hypoglycemia, performing moderate glucose control and minimizing glucose variability are important concepts in glycemic management, but the optimal target range remains unknown. Dysnatremia seems to be associated with negative outcomes. It is not clear yet that maintaining normonatremia actively improves neurological outcomes. Optimal duration of intensive care management has not been determined.
\end{abstract}

Short conclusion: Although we have an advanced understanding of the pathophysiology and clinical characteristics of subarachnoid hemorrhage, there are many controversies in the intensive care unit management of subarachnoid hemorrhage. With an awareness of not only delayed cerebral ischemia but also early brain injury, more attention should be given to various aspects to improve neurological outcomes.

Keywords: Aneurysmal subarachnoid hemorrhage, Delayed cerebral ischemia, Early brain injury, Sympathetic activity, Hemodynamic management, Fever management, Glycemic management, Dysnatremia, Duration of intensive care management

\footnotetext{
* Correspondence: tomoyaokazaki4028@gmail.com

${ }^{1}$ Emergency Medical Center, Kagawa University Hospital, 1750-1 Ikenobe,

Miki, Kita, Kagawa 761-0793, Japan

Full list of author information is available at the end of the article
}

(c) The Author(s). 2018 Open Access This article is distributed under the terms of the Creative Commons Attribution 4.0 International License (http://creativecommons.org/licenses/by/4.0/), which permits unrestricted use, distribution, and reproduction in any medium, provided you give appropriate credit to the original author(s) and the source, provide a link to the Creative Commons license, and indicate if changes were made. The Creative Commons Public Domain Dedication waiver (http://creativecommons.org/publicdomain/zero/1.0/) applies to the data made available in this article, unless otherwise stated. 


\section{Background}

Aneurysmal subarachnoid hemorrhage (SAH) is known to be associated with high mortality, morbidity, and burden of healthcare $[1,2]$. SAH is one of the main targets of neurocritical care [3-5]. Delayed cerebral ischemia (DCI) is a well-known complication that usually develops in one third of SAH patients between 4 and 14 days after the hemorrhage [2]. A definition of DCI for clinical trials and observational studies was proposed in 2010 [6]. Cerebral vasospasm was thought to be the main cause of DCI, and several studies on the prevention of cerebral vasospasm have been conducted. As an example, clazosentan, an endothelin receptor antagonist, significantly decreased vasospasm compared with placebo [7] but failed to improve functional outcome [8]. A randomized controlled trial (RCT) of fasudil reached the same results [9]. These findings suggested two possibilities: First, factors other than cerebral vasospasm have an important role in the development of DCI. Second, factors other than DCI have profound effects on neurological outcomes. Our target is not cerebral vasospasm but improving neurological outcomes. The purpose of this review is to discuss what intensivists should know and can do to improve clinical outcomes in SAH patients.

\section{Review}

\section{Concept of $\mathrm{DCl}$ and early brain injury}

Although a clear picture of DCI remains unknown, human and animal studies have suggested that several pathophysiological mechanisms contribute to development of DCI. These mechanisms are cerebral vascular dysregulation, including cerebral vasospasm and microcirculatory dysfunction, microthrombosis, cortical spreading depolarization, and neuroinflammation [10].
We cannot discuss each factor in detail in the current review.

A concept of early brain injury (EBI) for the immediate brain injury during the first $72 \mathrm{~h}$ after the hemorrhage has been proposed over the past years [11]. EBI is another factor that affects neurological outcome. Aneurysmal rupture leads to transient global ischemia, which is caused by increasing intracranial pressure, decreasing cerebral perfusion pressure, and decreasing cerebral blood flow, and toxic activity of the subarachnoid hemorrhage. These mechanisms induce multifactorial derangement, such as microcirculatory constriction, endothelial cell apoptosis, blood-brain barrier disruption, brain edema, and thromboinflammatory cascade $[1,12]$.

Figure 1 shows an overview of EBI and DCI. It is important to bear in mind that both DCI and EBI involve multiple pathophysiological factors. It helps us to interpret basic and clinical trials in the past and future.

\section{Management of sympathetic activity}

Increasing sympathetic activity and excessive catecholamine release have received constant attention [13]. Recent studies have shown that acute catecholamine surge occurring immediately after the hemorrhage resulted in cardiopulmonary complications such as neurogenicstunned myocardium and neurogenic pulmonary edema [14]. An association between serum catecholamine concentration and poor neurological outcome has been reported in some observational studies $[13,15]$.

Serum lactate measurement is very easy and common in intensive care units (ICUs). Elevated serum lactate level is due to not only tissue hypoxia but also aerobic glycolysis caused by excessive catecholamine release [16]. Elevated serum lactate levels during the acute phase in SAH patients seem natural in theory. A

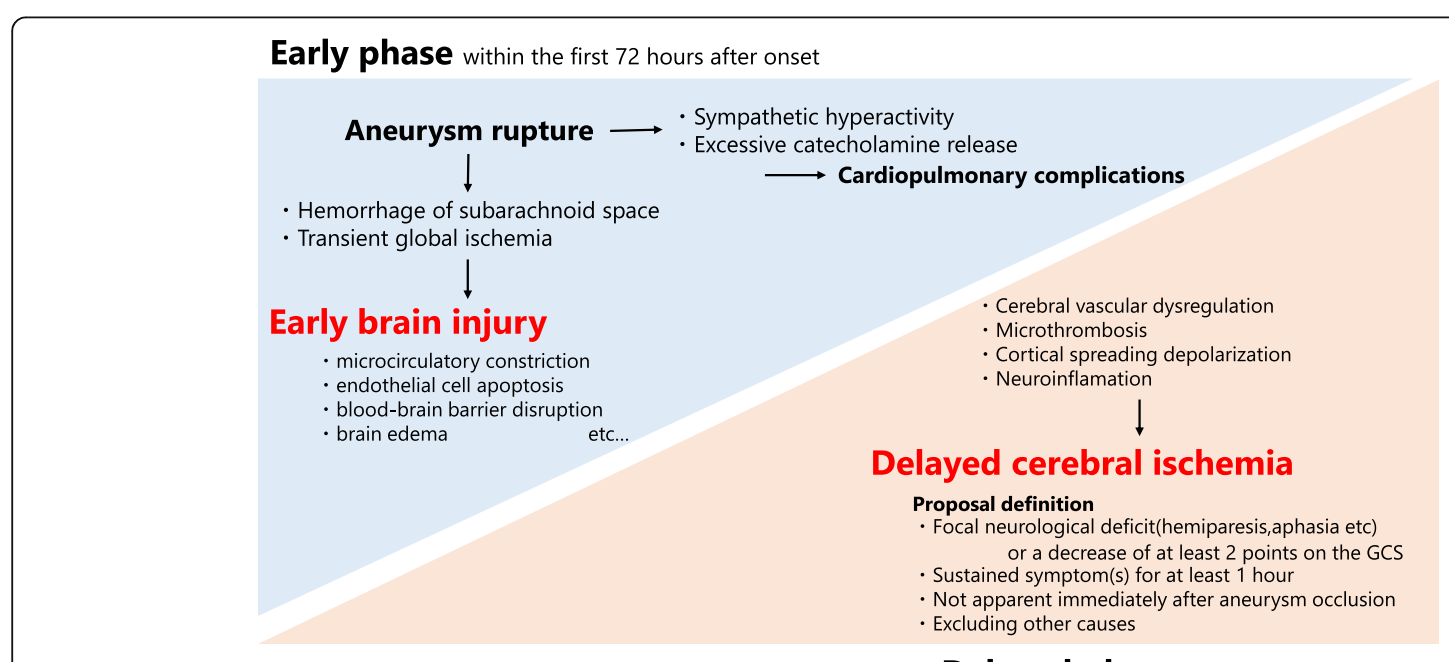

Delayed phase from 72 hours onward

Fig. 1 Overview of early brain injury and delayed cerebral ischemia in subarachnoid hemorrhage patients 
retrospective study with 145 patients revealed the alteration of serum lactate levels during ICU stays [17]. In this study, the elevated serum lactate levels on admission gradually decreased to the normal range. Three retrospective observational studies found that elevated serum lactate levels in the acute phase were associated with mortality and poor neurological outcomes [17-19]. Although further studies are warranted, serum lactate measurement may be a valuable marker reflecting the severity of sympathetic activity and excessive catecholamine release. However, serum lactate level is significantly affected by anaerobic glycolysis. Physicians should identify factors causing decreased oxygen delivery to tissues that may result from conditions such as cardiogenic or hypovolemic shock, sepsis, and severe anemia [20]. As discussed in the later sections, fluid volume status is crucial in the ICU management of SAH patients. To the best of our knowledge, there are no reports regarding the utility of lactate-guided evaluation of volume status in $\mathrm{SAH}$ patients.

There have been few studies on the management of sympathetic activity. A meta-analysis of three retrospective studies showed that preadmission beta blockers did not decrease cardiac dysfunction or mortality [21]. The association of dexmedetomidine with neurological outcomes was explored in a single-center retrospective observational study [22]. This study found that low-dosage dexmedetomidine during the first $24 \mathrm{~h}$ after admission had better lactate clearance and was associated with favorable neurological outcomes. However, there were many confounding factors in this study, and the causal relationship between dexmedetomidine and clinical outcomes remains unknown.

\section{Hemodynamic management}

Although prophylactic triple-H therapy (hypervolemia, hypertension, hemodilution) for preventing DCI was acceptable [23], current evidence does not support its efficacy and recommends maintaining normovolemia [2426]. Induced hypertension and volume status have been regarded as important.

Based on several case series, induced hypertension was a highly anticipated intervention for patients with DCI [27]. An RCT was designed to evaluate the effectiveness of induced hypertension; however, this trial was prematurely terminated because of its ineffectiveness for cerebral perfusion and slow recruitment [27]. Currently, there is no way to treat DCI definitively. Therefore, we should perform appropriate interventions, including induced hypertension and endovascular treatment, according to the needs of individual patients [28].

It is difficult to accurately evaluate volume status and maintain normovolemia. The transpulmonary thermodilution (TPTD) method can measure various hemodynamic parameters [29]. Several studies have reported the utility of TPTD in SAH management. A multicenter prospective cohort study showed that a lower global end-diastolic volume index as an indicator of cardiac preload during the first week was associated with the occurrence of DCI, and its threshold was slightly higher than the normal value $\left(822 \mathrm{~mL} / \mathrm{m}^{2}\right)$ [30]. Additionally, the association between prophylactic triple- $\mathrm{H}$ therapy and global end-diastolic volume index was evaluated using the TPTD study data [31]. Accordingly, patients were divided into two groups based on whether or not they were under prophylactic triple- $\mathrm{H}$ therapy. Patients in the triple- $\mathrm{H}$ therapy group had a greater amount of fluid than the other group, but there were no significant differences in the global end-diastolic volume index and clinical outcomes between the groups. A physician-driven triple- $\mathrm{H}$ therapy could not effectively increase the global end-diastolic volume index; therefore, previous studies on triple- $\mathrm{H}$ therapy may fail to improve clinical outcomes. An RCT was performed to assess the efficacy of TPTD-based management compared with fluid balance or central venous pressure-guided management [32]. However, TPTD-based management neither decreased DCI nor improved functional outcomes. A possible reason is that the TPTD-based management protocol was not established using an SAH-specific cutoff value. Although there will be additional knowledge concerning hemodynamics in SAH gained from the use of the TPTD method, how to translate the TPTD evidence for use in less invasive methods is a future issue.

\section{Fever management}

Fever is defined as a body temperature $>38.3{ }^{\circ} \mathrm{C}$ and is a well-recognized symptom experienced by $70 \%$ of patients with SAH [33, 34]. Poor clinical grade on admission and intraventricular hemorrhage are regarded as risk factors for fever in SAH patients [34]. Several retrospective or prospective observational studies showed that fever was significantly associated with mortality and poor neurological outcome [34-36]. Based on these findings and those from studies with animal $\mathrm{SAH}$ models clarifying the neuroprotective effect of targeted temperature management (TTM) [37, 38], the benefit of TTM for SAH patients was assessed in several studies. Studies exploring the association between TTM and clinical outcomes are summarized in Table 1 [39-43]. A study of TTM for refractory intracranial pressure elevation was excluded [44]. As indicated in Table 1, there are many differences among the studies with regard to the purpose of TTM (treatment of refractory fever or prevention of fever), protocol of TTM (initiation timing, target temperature, duration of target temperature, and rewarming rate), and method of TTM. These differences may produce varying results. A prospective, multi-center RCT to evaluate the efficacy of TTM $\left(32-35{ }^{\circ} \mathrm{C}\right.$ for a 
Table 1 Summary of targeted temperature management studies

\begin{tabular}{|c|c|c|c|c|c|}
\hline Article & Design & Patient & Intervention or exposure & Comparison & Main results \\
\hline Muroi C 2008 [39] & $\begin{array}{l}\text { Single-center, } \\
\text { prospective cohort } \\
\text { study }\end{array}$ & $\begin{array}{l}\text { SAH patients with } \\
\text { a ventricular catheter } \\
\text { for cerebrospinal fluid } \\
\text { drainage }\end{array}$ & $\begin{array}{l}\text { (1) } 33^{\circ} \mathrm{C} \text { with an } \\
\text { endovascular cooling } \\
\text { device } \\
\text { (2) Barbiturate coma } \\
N=7\end{array}$ & $\begin{array}{l}\text { No detail described } \\
N=8\end{array}$ & $\begin{array}{l}\text { There was no significant } \\
\text { difference in neurological } \\
\text { outcome }(G O S>3) \text { at } \\
1 \text { year ( } 42.9 \text { vs. } 50.0 \%) \text {. }\end{array}$ \\
\hline Anei R 2010 [40] & $\begin{array}{l}\text { Single-center } \\
\text { Before-after study }\end{array}$ & $\begin{array}{l}\text { Poor-grade SAH patients } \\
\text { (WFNS scale }>3 \text { ) }\end{array}$ & $\begin{array}{l}\text { (1) Induction within } \\
24 \mathrm{~h} \text { after the } \\
\text { hemorrhage } \\
\text { (2) } 34^{\circ} \mathrm{C} \text { for } 48 \mathrm{~h} \text { with } \\
\text { an cooling blanket } \\
\text { (3) Rewarming at the } \\
\text { rate of } 1^{\circ} \mathrm{C} / 24 \mathrm{~h} \\
\mathrm{~N}=16\end{array}$ & $\begin{array}{l}\text { No detail described } \\
N=19\end{array}$ & $\begin{array}{l}\text { There was no significant } \\
\text { difference in neurological } \\
\text { outcome at } 3 \text { months. }\end{array}$ \\
\hline Badjatia N 2010 [41] & $\begin{array}{l}\text { Matched controlled } \\
\text { analysis from single- } \\
\text { center, prospective } \\
\text { cohort }\end{array}$ & $\begin{array}{l}\text { SAH patients with } \\
\text { antipyretic-resistant } \\
\text { fever }\end{array}$ & $\begin{array}{l}37^{\circ} \mathrm{C} \text { for } 14 \text { days with } \\
\text { a surface cooling device } \\
N=40\end{array}$ & $\begin{array}{l}\text { Oral acetaminophen } \\
\text { with or without use } \\
\text { of a water-circulating } \\
\text { blanket } \\
N=80\end{array}$ & $\begin{array}{l}\text { In multivariate analysis, } \\
\text { TTM was associated with } \\
\text { better neurological } \\
\text { outcome at } 12 \text { months } \\
\text { (79 vs. } 54 \%) \text {. }\end{array}$ \\
\hline Kuramatsu JB 2015 [42] & $\begin{array}{l}\text { Matched controlled } \\
\text { analysis from single- } \\
\text { center, prospective } \\
\text { cohort }\end{array}$ & $\begin{array}{l}\text { Poor-grade SAH patients } \\
\text { (Hunt and Hess grade } \\
>3 \text { and WFNS scale }>3 \text { ) }\end{array}$ & $\begin{array}{l}\text { (1) Induction within } \\
48 \mathrm{~h} \text { after the } \\
\text { hemorrhage } \\
\text { (2) } 35^{\circ} \mathrm{C} \text { for } 7 \text { days } \\
\text { with an endovascular } \\
\text { cooling device } \\
\text { (3) Rewarming at the } \\
\text { rate of } 0.5^{\circ} \mathrm{C} / 24 \mathrm{~h} \\
\mathrm{~N}=12\end{array}$ & $\begin{array}{l}\text { Intravenous } \\
\text { paracetamol } \\
N=24\end{array}$ & $\begin{array}{l}\text { Patients in TTM groups } \\
\text { had a significantly lower } \\
\text { incidence of DCI ( } 50.0 \text { vs. } \\
84.5 \%) \text { and a tendency to } \\
\text { have better functional } \\
\text { outcome (mRS < 3) at } \\
6 \text { months ( } 66.7 \text { vs. } 33.3 \%) \text {. }\end{array}$ \\
\hline Choi W 2017 [43] & $\begin{array}{l}\text { Single-center, } \\
\text { randomized control } \\
\text { trial }\end{array}$ & $\begin{array}{l}\text { Poor-grade SAH } \\
\text { patients (Hunt and } \\
\text { Hess grade }>3 \text { and } \\
\text { modified Fisher scale } \\
>2 \text { ) }\end{array}$ & $\begin{array}{l}\text { (1) Induction as soon } \\
\text { as possible after } \\
\text { ruptured aneurysmal } \\
\text { treatment } \\
\text { (2) } 34.5^{\circ} \mathrm{C} \text { for } 48 \mathrm{~h} \\
\text { with an endovascular } \\
\text { cooling device or a } \\
\text { surface cooling device } \\
\text { (3) rewarming at the } \\
\text { rate of } 1^{\circ} \mathrm{C} / 24 \text { h to } \\
36.5^{\circ} \mathrm{C} \\
\mathrm{N}=11\end{array}$ & $\begin{array}{l}\text { No detail described } \\
N=11\end{array}$ & $\begin{array}{l}\text { There were no significant } \\
\text { differences in the } \\
\text { incidences of DCI ( } 36.3 \\
\text { vs. } 45.6 \% \text { ) and favorable } \\
\text { neurological outcome } \\
\text { (mRS }<3 \text { ) at } 3 \text { months } \\
\text { between two groups } \\
\text { ( } 27.3 \text { vs. } 9.1 \%) \text {. }\end{array}$ \\
\hline
\end{tabular}

SAH subarachnoid hemorrhage, TTM targeted temperature management, WFNS World Federation of Neurosurgical Society, DCI delayed cerebral ischemia, mRS modified Ranking scale score, GOS Glasgow outcome scale

minimum of 5 days) for patients with poor-grade SAH is registered on ClinicalTrials.gov [45]. Although this trial will not be able to provide solid answers, it will provide some information regarding when, how, and on whom TTM is to be performed.

In the current scenario, clinicians must clearly not neglect efforts to identify potential causes of fever. In case of TTM, controlling shivering should be emphasized.

\section{Glycemic management}

Hyperglycemia is frequently observed in SAH patients and is independently associated with poor outcomes [26]. Although hyperglycemia on admission may be merely a marker of severity, an association of worse outcomes with persistent hyperglycemia has been reported [46], and an early correction of hyperglycemia is considered reasonable. The European Stroke Organization guidelines recommend that hyperglycemia with blood glucose $>10 \mathrm{mmol} / \mathrm{L}(180 \mathrm{mg} / \mathrm{dL})$ should be treated [26]. However, there is no evidence supporting this cutoff value.

Hypoglycemia is associated with negative outcomes in SAH patients [47] as in general critically ill patients [48]. However, the optimal cutoff value of hypoglycemia in SAH patients has not been established [24-26]. A retrospective observational study found that $>50 \%$ of $\mathrm{SAH}$ patients with minimum glucose $<8 \mathrm{mmol} / \mathrm{L}(90 \mathrm{mg} / \mathrm{dL})$ had unfavorable outcomes at discharge [49]. Especially during insulin infusion, cerebral interstitial hypoglycemia has been shown to occur despite the absence of blood hypoglycemia in two cerebral microdialysis studies [50, 51]. It may be innocuous to set a higher threshold in SAH patients than in critically ill patients.

Optimal glycemic control in SAH patients has been discussed in two before-after studies and one RCT (Table 2). One before-after study showed that a strict 
Table 2 Summary of glycemic control studies

\begin{tabular}{|c|c|c|c|c|c|c|}
\hline Article & Design & Patient & $\begin{array}{l}\text { Intervention or } \\
\text { exposure }\end{array}$ & Comparison & Outcome & Main results \\
\hline $\begin{array}{l}\text { Thiele RH } 2009 \\
\text { [52] }\end{array}$ & $\begin{array}{l}\text { Single-center } \\
\text { Before-after } \\
\text { study }\end{array}$ & $\begin{array}{l}\text { Patients with the primary } \\
\text { diagnosis of SAH }\end{array}$ & $\begin{array}{l}5.0-6.7 \mathrm{mmol} / \mathrm{l} \\
(90-120 \mathrm{mg} / \mathrm{dl}) \\
N=491\end{array}$ & $\begin{array}{l}\text { No detail } \\
\text { described } \\
N=343\end{array}$ & In-hospital mortality & $\begin{array}{l}\text { Three was no significant } \\
\text { difference in in-hospital } \\
\text { mortality. }\end{array}$ \\
\hline $\begin{array}{l}\text { Latorre JG } 2009 \\
\text { [53] }\end{array}$ & $\begin{array}{l}\text { Single-center } \\
\text { Before-after } \\
\text { study }\end{array}$ & $\begin{array}{l}\text { SAH patients with blood } \\
\text { glucose }>11.1 \mathrm{mmol} / \mathrm{l} \\
\text { ( } 200 \mathrm{mg} / \mathrm{dl}) \text { on admission } \\
\text { or the first } 24 \mathrm{~h} \text { mean } \\
\text { blood glucose }>7.8 \\
\mathrm{mmol} / \mathrm{l}(140 \mathrm{mg} / \mathrm{dL})\end{array}$ & $\begin{array}{l}4.4-7.8 \mathrm{mmol} / \mathrm{l} \\
(80-140 \mathrm{mg} / \mathrm{dl}) \\
N=166\end{array}$ & $\begin{array}{l}\leqq 11.1 \mathrm{mmol} / \mathrm{l} \\
(200 \mathrm{mg} / \mathrm{dl}) \\
N=166\end{array}$ & $\mathrm{mRS} \geqq 4$ at $3-6$ months & $\begin{array}{l}\text { Given temporal trend, } \\
\text { there was no significant } \\
\text { difference in neurological } \\
\text { outcome. }\end{array}$ \\
\hline $\begin{array}{l}\text { Bilotta F. } 2007 \\
\text { [54] }\end{array}$ & $\begin{array}{l}\text { Single-center, } \\
\text { randomized } \\
\text { control trial }\end{array}$ & $\begin{array}{l}\text { SAH patients undergoing } \\
\text { emergency cerebral } \\
\text { aneurysm clipping }\end{array}$ & $\begin{array}{l}4.4-6.7 \mathrm{mmol} / \mathrm{l} \\
(80-120 \mathrm{mg} / \mathrm{dl}) \\
\mathrm{N}=40\end{array}$ & $\begin{array}{l}4.4-12.2 \mathrm{mmol} / \mathrm{l} \\
(80-220 \mathrm{mg} / \mathrm{d}) \\
\mathrm{N}=38\end{array}$ & $\begin{array}{l}\mathrm{mRS} \geqq 4 \text { at } 6 \text { months } \\
\text { (as secondary outcome) }\end{array}$ & $\begin{array}{l}\text { There was no significant } \\
\text { difference in neurological } \\
\text { outcome. }\end{array}$ \\
\hline
\end{tabular}

mRS modified Ranking Scale score

glucose control regimen $(5.0-6.7 \mathrm{mmol} / \mathrm{L} ; 90-$ $120 \mathrm{mg} / \mathrm{dL}$ ) failed to reduce mortality and was associated with the incidence of hypoglycemia [52]. Another before-after study showed that an aggressive hyperglycemia management protocol $(4.4-7.8 \mathrm{mmol} / \mathrm{L}(80-$ $140 \mathrm{mg} / \mathrm{dL})$ ) did not improve time trend-adjusted neurological outcomes [53]. An RCT performed with a small number of patients after surgical clipping found that intensive insulin therapy $(4.4-6.7 \mathrm{mmol} / \mathrm{L}$; 80-120 mg/dL) compared with maintaining blood glucose $<11.1 \mathrm{mmol} / \mathrm{L}(200 \mathrm{mg} / \mathrm{dL})$ significantly reduced infection rates as the primary endpoint, but there was no significant difference in the neurological outcomes between the two groups [54]. On the basis of the above findings, it seems that strict glycemic control provides little benefit and increases the risk of hypoglycemia.

Three retrospective observational studies have suggested that glucose variability was associated with cerebral infarction, mortality, and poor neurological outcomes $[49,55,56]$. A cerebral microdialysis study of 28 comatose SAH patients showed that systemic glucose variability was associated with cerebral metabolic distress [56]. Another microdialysis study found that an acute decrease in blood glucose, despite being within normal range, was associated with brain energy metabolic crisis and an elevated lactate/pyruvate ratio [57]. We should be careful not to make extensive changes in blood glucose concentrations.

In addition to these issues, there are two questions about glycemic management in SAH patients: First, what is the effect of pre-existing impaired glucose tolerance? Previous studies have reported that diabetic status affected the association of hyperglycemia, hypoglycemia, and glucose variability with mortality in critically ill patients [58, 59]. Second, can we apply the same glycemic management during both the EBI and DCI period? These questions have never been explored.

\section{Dysnatremia management}

Both hyponatremia and hypernatremia commonly occur in the ICU management in SAH patients [25]. However, there are few studies describing the characteristics of sodium alteration in ICU. A single-center retrospective observational study showed that serum sodium concentrations increased for the first few days and decreased to the nadir level at 612 days [60]. A similar trend was observed in another retrospective study [61].

Hyponatremia, defined as serum sodium levels < $135 \mathrm{mmol} / \mathrm{L}$, occurs in one third of SAH patients [62] and is triggered by multifactorial causes, which include hypovolemia, a syndrome involving inappropriate secretion of antidiuretic hormone, glucocorticoid deficiency, and cerebral salt-wasting syndrome and its interactions [63, 64]. Although a systematic review showed that hyponatremia was associated with longer hospitalization and cerebral infarction, whether hyponatremia affects neurological outcomes remains controversial [62]. The threshold of hyponatremia associated with poor neurological outcomes was addressed in a retrospective observational study involving 131 patients [60]. In this study, multiple regression analysis showed that minimum sodium levels in the ICU were associated with unfavorable neurological outcomes at hospital discharge, and receiver operating characteristics curve analysis derived a cutoff value of $132 \mathrm{mmol} / \mathrm{L}$. According to a systematic review on prevention and treatment of hyponatremia, mineralocorticoids use reduced natriuresis and volume contraction but did not improve neurological outcomes [65].

Hypernatremia is commonly defined as serum sodium levels $>145 \mathrm{mmol} / \mathrm{L}$ and develops less frequently than hyponatremia [60]. SAH-related hypothalamic dysfunction induces central diabetes insipidus followed by hypernatremia [66, 67]. The association of hypernatremia with clinical outcomes is summarized in Table 3 [67-72].

Referring to this summary, the optimal threshold seemed to be $145 \mathrm{mmol} / \mathrm{L}$, as suggested in a previous study [60], and hypernatremia was associated with poor 
Table 3 Summary of the association between hypernatremia and clinical outcomes

\begin{tabular}{|c|c|c|c|c|c|c|}
\hline Article & Study design & $\begin{array}{l}\text { Definition of } \\
\text { hypernatremia } \\
\text { (mmol/L) }\end{array}$ & $\begin{array}{l}\text { Number of patient } \\
\text { with hypernatremia/ } \\
\text { total number of patients }\end{array}$ & $\begin{array}{l}\text { In-hospital } \\
\text { mortality }\end{array}$ & $\begin{array}{l}\text { Delayed cerebral } \\
\text { ischemia }\end{array}$ & $\begin{array}{l}\text { Neurological } \\
\text { outcome }\end{array}$ \\
\hline Qureshi Al 2002 [68] & Post hoc analysis of RCT & $>145$ & $58 / 298(19.5 \%)$ & NA & NA & $\begin{array}{l}\text { Worse at } 3 \\
\text { months }\end{array}$ \\
\hline $\begin{array}{l}\text { Wartenberg KE } \\
2006 \text { [69] }\end{array}$ & $\begin{array}{l}\text { Post hoc analysis of single- } \\
\text { center, prospective cohort } \\
\text { study }\end{array}$ & $>150$ & $91 / 576(15.8 \%)$ & NA & NA & $\begin{array}{l}\text { Not significant } \\
\text { at } 3 \text { months }\end{array}$ \\
\hline Fisher LA 2006 [70] & $\begin{array}{l}\text { Post hoc analysis of single- } \\
\text { center, prospective cohort } \\
\text { study }\end{array}$ & $>143$ & $48 / 214(22.4 \%)$ & $\begin{array}{l}\text { Not } \\
\text { significant }\end{array}$ & NA & NA \\
\hline Beseoglu K 2014 [67] & $\begin{array}{l}\text { Single-center, retrospective } \\
\text { cohort study }\end{array}$ & $>145$ & $82 / 264(31.1 \%)$ & NA & NA & $\begin{array}{l}\text { Worse at } \\
12 \text { months }\end{array}$ \\
\hline Lantigua H 2015 [71] & $\begin{array}{l}\text { Post hoc analysis of single- } \\
\text { center, prospective cohort } \\
\text { study }\end{array}$ & $>150$ & 250/1200 (20.8\%) & Higher & NA & NA \\
\hline Spatenkova V 2017 [72] & $\begin{array}{l}\text { Single-center, retrospective } \\
\text { and prospective observational } \\
\text { study }\end{array}$ & $>150$ & 41/334 (11.9\%) & Higher & NA & $\begin{array}{l}\text { Worse at } \\
12 \text { months }\end{array}$ \\
\hline Okazaki T 2017 [60] ${ }^{a}$ & $\begin{array}{l}\text { Single-center, retrospective } \\
\text { observational study }\end{array}$ & $\geqq 145$ & 40/131 (30.5\%) & NA & NA & $\begin{array}{l}\text { Worse at } \\
\text { hospital } \\
\text { discharge }\end{array}$ \\
\hline
\end{tabular}

NA not applicable

${ }^{a}$ Result from additional data analysis

outcomes. The preventive effect of a specific drug or protocol on hypernatremia has not been tested to date.

Given the above findings, it remains unknown if there is a causal relationship between dysnatremia and clinical outcomes. Additional studies are required to evaluate whether maintaining normonatremia actively improves neurological outcomes.

\section{Duration of intensive care management}

As discussed, physicians should perform multimodality monitoring and optimal intervention as needed for $\mathrm{SAH}$ patients. The duration of continuing intensive care, especially in stable patients without neurological deficit after aneurysmal treatment, should be determined. Subgroup analysis in $\mathrm{SAH}$ patients with Hunt and Kosnik grades I-II of a single-center before-after study gave us some clues regarding the duration of continuing intensive care [5]. This study showed that neurointensivistmanaged ICU implementation was associated with improved neurological outcome and with prolonged ICU stay [median (interquartile range), $12(9-14.3)$ vs. 3 (1. $5-10.5)$ days, $p<0.01]$. Another before-after study exploring the beneficial effect of neurointensivist on discharge disposition also demonstrated similar results (length of ICU stay: mean \pm standard deviation days, 11 . $6 \pm 11.0$ vs. $3.7 \pm 12.4, p<0.01$ ) [4]. Approximately 12 days of ICU stay, as observed in these studies, may roughly indicate the duration required to prevent, detect, and deal with subsequent complications. However, further studies are warranted to determine whether longer
ICU stay can contribute to improved outcomes in goodgrade SAH patients and whether ICU stay can be safely reduced.

\section{Conclusions}

Although we have an advanced understanding of the pathophysiology and clinical characteristics of SAH, there are many controversies in the ICU management of SAH. With an awareness of not only DCI but also EBI, more attention should be given to various aspects, including sympathetic activity, hemodynamic management, glycemic management, dysnatremia, and duration of intensive care management to improve neurological outcomes.

\section{Abbreviations}

DCI: Delayed cerebral ischemia; EBI: Early brain injury; ICU: Intensive care unit; RCT: Randomized controlled trial; SAH: Subarachnoid hemorrhage;

TPTD: Transpulmonary thermodilution

\section{Authors' contributions}

TO drafted the manuscript. YK supervised the manuscript. Both authors read and approved the manuscript.

Ethics approval and consent to participate Not applicable.

Competing interests

The authors declare that they have no competing interests.

\section{Publisher's Note}

Springer Nature remains neutral with regard to jurisdictional claims in published maps and institutional affiliations. 


\section{Author details}

'Emergency Medical Center, Kagawa University Hospital, 1750-1 Ikenobe, Miki, Kita, Kagawa 761-0793, Japan. ${ }^{2}$ Department of Emergency, Disaster, and Critical Care Medicine, Faculty of Medicine, Kagawa University, 1750-1, Ikenobe, Miki, Kita, Kagawa 761-0793, Japan.

\section{Received: 22 February 2018 Accepted: 29 April 2018} Published online: 08 May 2018

\section{References}

1. Macdonald RL, Schweizer TA. Spontaneous subarachnoid haemorrhage. Lancet. 2017;389:655-66.

2. Lawton MT, Vates GE. Subarachnoid hemorrhage. N Engl J Med. 2017;377: 257-66.

3. Samuels O, Webb A, Culler S, Martin K, Barrow D. Impact of a dedicated neurocritical care team in treating patients with aneurysmal subarachnoid hemorrhage. Neurocrit Care. 2011;14:334-40.

4. Knopf L, Staff I, Gomes J, McCullough L. Impact of a neurointensivist on outcomes in critically ill stroke patients. Neurocrit Care. 2012;16:63-71.

5. Egawa S, Hifumi T, Kawakita K, Okauchi M, Shindo A, Kawanishi M, et al. Impact of neurointensivist-managed intensive care unit implementation on patient outcomes after aneurysmal subarachnoid hemorrhage. J Crit Care. 2016;32:52-5.

6. Vergouwen MD, Vermeulen M, van Gijn J, Rinkel GJ, Wijdicks EF, Muizelaar $J$, et al. Definition of delayed cerebral ischemia after aneurysmal subarachnoid hemorrhage as an outcome event in clinical trials and observational studies: proposal of a multidisciplinary research group. Stroke. 2010:41:2391-5.

7. Macdonald RL, Kassell NF, Mayer S, Ruefenacht D, Schmiedek P, Weidauer S, et al. Clazosentan to overcome neurological ischemia and infarction occurring after subarachnoid hemorrhage (CONSCIOUS-1): randomized, double-blind, placebo-controlled phase 2 dose-finding trial. Stroke. 2008;39: 3015-21.

8. Macdonald RL, Higashida RT, Keller E, Mayer SA, Molyneux A, Raabe A, et al. Clazosentan, an endothelin receptor antagonist, in patients with aneurysmal subarachnoid haemorrhage undergoing surgical clipping: a randomised, double-blind, placebo-controlled phase 3 trial (CONSCIOUS-2). Lancet Neurol. 2011;10:618-25.

9. Shibuya M, Suzuki Y, Sugita K, Saito I, Sasaki T, Takakura K, et al. Effect of AT877 on cerebral vasospasm after aneurysmal subarachnoid hemorrhage. Results of a prospective placebo-controlled double-blind trial. J Neurosurg. 1992;76:571-7.

10. Geraghty JR, Testai FD. Delayed cerebral ischemia after subarachnoid hemorrhage: beyond vasospasm and towards a multifactorial pathophysiology. Curr Atheroscler Rep. 2017;19:50.

11. Kusaka G, Ishikawa M, Nanda A, Granger DN, Zhang JH. Signaling pathways for early brain injury after subarachnoid hemorrhage. J Cereb Blood Flow Metab. 2004;24:916-25.

12. Fujii M, Yan J, Rolland WB, Soejima Y, Caner B, Zhang JH. Early brain injury, an evolving frontier in subarachnoid hemorrhage research. Transl Stroke Res. 2013;4:432-46.

13. Benedict CR, Loach AB. Sympathetic nervous system activity in patients with subarachnoid hemorrhage. Stroke. 1978;9:237-44.

14. Hall A, O'Kane R. The extracranial consequences of subarachnoid hemorrhage. World Neurosurg. 2018;109:381-92.

15. Ogura T, Satoh A, Ooigawa H, Sugiyama T, Takeda R, Fushihara G, et al. Characteristics and prognostic value of acute catecholamine surge in patients with aneurysmal subarachnoid hemorrhage. Neurol Res. 2012; 34:484-90.

16. Bakker J, Nijsten MW, Jansen TC. Clinical use of lactate monitoring in critically ill patients. Ann Intensive Care. 2013;3:12.

17. Okazaki T, Hifumi T, Kawakita K, Shishido H, Ogawa D, Okauchi M, et al. Serial blood lactate measurements and its prognostic significance in intensive care unit management of aneurysmal subarachnoid hemorrhage patients. J Crit Care. 2017:41:229-33.

18. Aisiku IP, Chen PR, Truong H, Monsivais DR, Edlow J. Admission serum lactate predicts mortality in aneurysmal subarachnoid hemorrhage. Am J Emerg Med. 2016:34:708-12.

19. van Donkelaar CE, Dijkland SA, van den Bergh WM, Bakker J, Dippel DW, Nijsten MW, et al. Early circulating lactate and glucose levels after aneurysmal subarachnoid hemorrhage correlate with poor outcome and delayed cerebral ischemia: a two-center cohort study. Crit Care Med. 2016; 44:966-72.

20. Kraut JA, Madias NE. Lactic acidosis. N Engl J Med. 2014;371:2309-19.

21. Luo H, Song WX, Jiang JW, Zhao JL, Rong WL, Li MH. Effects of preadmission beta-blockers on neurogenic stunned myocardium after aneurysmal subarachnoid hemorrhage: a meta-analysis. Clin Neurol Neurosurg. 2017;158:77-81.

22. Okazaki T, Hifumi T, Kawakita K, Shishido H, Ogawa D, Okauchi M, et al. Association between dexmedetomidine use and neurological outcomes in aneurysmal subarachnoid hemorrhage patients: a retrospective observational study. J Crit Care. 2017:44:111-6.

23. Meyer R, Deem S, Yanez ND, Souter M, Lam A, Treggiari MM. Current practices of triple-H prophylaxis and therapy in patients with subarachnoid hemorrhage. Neurocrit Care. 2011;14:24-36.

24. Diringer MN, Bleck TP, Claude Hemphill J 3rd, Menon D, Shutter L, Vespa P, et al. Critical care management of patients following aneurysmal subarachnoid hemorrhage: recommendations from the Neurocritical Care Society's Multidisciplinary Consensus Conference. Neurocrit Care. 2011;15:211-40.

25. Connolly ES Jr, Rabinstein AA, Carhuapoma JR, Derdeyn CP, Dion J, Higashida RT, et al. Guidelines for the management of aneurysmal subarachnoid hemorrhage: a guideline for healthcare professionals from the American Heart Association/American Stroke Association. Stroke. 2012;43: 1711-37.

26. Steiner T, Juvela S, Unterberg A, Jung C, Forsting M, Rinkel G. European Stroke Organization guidelines for the management of intracranial aneurysms and subarachnoid haemorrhage. Cerebrovasc Dis. 2013;35:93-112.

27. Gathier CS, van den Bergh WM, van der Jagt M, Verweij BH, Dankbaar JW Muller MC, et al. Induced hypertension for delayed cerebral ischemia after aneurysmal subarachnoid hemorrhage: a randomized clinical trial. Stroke. 2018:49:76-83.

28. Francoeur $\mathrm{CL}$, Mayer SA. Management of delayed cerebral ischemia after subarachnoid hemorrhage. Crit Care. 2016:20:277.

29. Monnet $X$, Teboul JL. Transpulmonary thermodilution: advantages and limits. Crit Care. 2017:21:147.

30. Tagami T, Kuwamoto K, Watanabe A, Unemoto K, Yokobori S, Matsumoto G, et al. Optimal range of global end-diastolic volume for fluid management after aneurysmal subarachnoid hemorrhage: a multicenter prospective cohort study. Crit Care Med. 2014:42:1348-56.

31. Tagami T, Kuwamoto K, Watanabe A, Unemoto K, Yokobori S, Matsumoto G, et al. Effect of triple-h prophylaxis on global end-diastolic volume and clinical outcomes in patients with aneurysmal subarachnoid hemorrhage. Neurocrit Care. 2014;21:462-9.

32. Mutoh T, Kazumata K, Terasaka S, Taki Y, Suzuki A, Ishikawa T. Early intensive versus minimally invasive approach to postoperative hemodynamic management after subarachnoid hemorrhage. Stroke. 2014;45:1280-4

33. Albrecht RF 2 nd, Wass CT, Lanier WL. Occurrence of potentially detrimental temperature alterations in hospitalized patients at risk for brain injury. Mayo Clin Proc. 1998;73:629-35.

34. Fernandez A, Schmidt JM, Claassen J, Pavlicova M, Huddleston D, Kreiter KT, et al. Fever after subarachnoid hemorrhage: risk factors and impact on outcome. Neurology. 2007;68:1013-9.

35. Naidech AM, Bendok BR, Bernstein RA, Alberts MJ, Batjer HH, Watts CM, et al. Fever burden and functional recovery after subarachnoid hemorrhage. Neurosurgery. 2008;63:212-7.

36. Kramer CL, Pegoli M, Mandrekar J, Lanzino G, Rabinstein AA. Refining the Association of Fever with functional outcome in aneurysmal subarachnoid hemorrhage. Neurocrit Care. 2017;26:41-7.

37. Torok E, Klopotowski M, Trabold R, Thal SC, Plesnila N, Scholler K. Mild hypothermia $\left(33^{\circ} \mathrm{C}\right)$ reduces intracranial hypertension and improves functional outcome after subarachnoid hemorrhage in rats. Neurosurgery. 2009;65:352-9.

38. Lv O, Zhou F, Zheng Y, Li Q, Wang J, Zhu Y. Mild hypothermia protects against early brain injury in rats following subarachnoid hemorrhage via the TrkB/ERK/CREB signaling pathway. Mol Med Rep. 2016;14:3901-7.

39. Muroi C, Frei K, El Beltagy M, Cesnulis E, Yonekawa Y, Keller E. Combined therapeutic hypothermia and barbiturate coma reduces interleukin-6 in the cerebrospinal fluid after aneurysmal subarachnoid hemorrhage. J Neurosurg Anesthesiol. 2008:20:193-8.

40. Anei R, Sakai H, lihara K, Nagata I. Effectiveness of brain hypothermia treatment in patients with severe subarachnoid hemorrhage: comparisons at a single facility. Neurol Med Chir (Tokyo). 2010;50:879-83. 
41. Badjatia N, Fernandez L, Schmidt JM, Lee K, Claassen J, Connolly ES, et al. Impact of induced normothermia on outcome after subarachnoid hemorrhage: a case-control study. Neurosurgery. 2010;66:696-700.

42. Kuramatsu JB, Kollmar R, Gerner ST, Madzar D, Pisarcikova A, Staykov D, et al. Is hypothermia helpful in severe subarachnoid hemorrhage? An exploratory study on macro vascular spasm, delayed cerebral infarction and functional outcome after prolonged hypothermia. Cerebrovasc Dis. 2015;40:228-35.

43. Choi W, Kwon SC, Lee WJ, Weon YC, Choi B, Lee H, et al. Feasibility and safety of mild therapeutic hypothermia in poor-grade subarachnoid hemorrhage: prospective pilot study. J Korean Med Sci. 2017;32:1337-44.

44. Karnatovskaia LV, Lee AS, Festic E, Kramer CL, Freeman WD. Effect of prolonged therapeutic hypothermia on intracranial pressure, organ function, and hospital outcomes among patients with aneurysmal subarachnoid hemorrhage. Neurocrit Care. 2014;21:451-61.

45. ClinicalTrials.gov. at https://clinicaltrials.gov/ct2/show/NCT03442608. Accessed 20 Apr 2018

46. McGirt MJ, Woodworth GF, Ali M, Than KD, Tamargo RJ, Clatterbuck RE. Persistent perioperative hyperglycemia as an independent predictor of poor outcome after aneurysmal subarachnoid hemorrhage. J Neurosurg. 2007; 107:1080-5.

47. Naidech AM, Levasseur K, Liebling S, Garg RK, Shapiro M, Ault ML, et al. Moderate hypoglycemia is associated with vasospasm, cerebral infarction, and 3-month disability after subarachnoid hemorrhage. Neurocrit Care. 2010;12:181-7.

48. Finfer S, Liu B, Chittock DR, Norton R, Myburgh JA, McArthur C, et al. Hypoglycemia and risk of death in critically ill patients. N Engl J Med. 2012;367:1108-18.

49. Okazaki T, Hifumi T, Kawakita K, Shishido H, Ogawa D, Okauchi M, et al. Blood glucose variability: a strong independent predictor of neurological outcomes in aneurysmal subarachnoid hemorrhage. J Intensive Care Med. 2018;33:189-95.

50. Schlenk F, Graetz D, Nagel A, Schmidt M, Sarrafzadeh AS. Insulin-related decrease in cerebral glucose despite normoglycemia in aneurysmal subarachnoid hemorrhage. Crit Care. 2008;12:R9.

51. Zetterling M, Hillered L, Enblad P, Karlsson T, Ronne-Engstrom E. Relation between brain interstitial and systemic glucose concentrations after subarachnoid hemorrhage. J Neurosurg. 2011;115:66-74.

52. Thiele RH, Pouratian N, Zuo Z, Scalzo DC, Dobbs HA, Dumont AS, et al. Strict glucose control does not affect mortality after aneurysmal subarachnoid hemorrhage. Anesthesiology. 2009;110:603-10.

53. Latorre JG, Chou SH, Nogueira RG, Singhal AB, Carter BS, Ogilvy CS, et al. Effective glycemic control with aggressive hyperglycemia management is associated with improved outcome in aneurysmal subarachnoid hemorrhage. Stroke. 2009;40:1644-52.

54. Bilotta F, Spinelli A, Giovannini F, Doronzio A, Delfini R, Rosa G. The effect of intensive insulin therapy on infection rate, vasospasm, neurologic outcome, and mortality in neurointensive care unit after intracranial aneurysm clipping in patients with acute subarachnoid hemorrhage: a randomized prospective pilot trial. J Neurosurg Anesthesiol. 2007;19:156-60.

55. Barletta JF, Figueroa BE, DeShane R, Blau SA, McAllen KJ. High glucose variability increases cerebral infarction in patients with spontaneous subarachnoid hemorrhage. J Crit Care. 2013;28:798-803.

56. Kurtz P, Claassen J, Helbok R, Schmidt J, Fernandez L, Presciutti M, et al. Systemic glucose variability predicts cerebral metabolic distress and mortality after subarachnoid hemorrhage: a retrospective observational study. Crit Care. 2014;18:R89.

57. Helbok R, Schmidt JM, Kurtz P, Hanafy KA, Fernandez L, Stuart RM, et al. Systemic glucose and brain energy metabolism after subarachnoid hemorrhage. Neurocrit Care. 2010;12:317-23.

58. Krinsley JS, Egi M, Kiss A, Devendra AN, Schuetz P, Maurer PM, et al. Diabetic status and the relation of the three domains of glycemic control to mortality in critically ill patients: an international multicenter cohort study. Crit Care. 2013;17:R37.

59. Egi M, Krinsley JS, Maurer P, Amin DN, Kanazawa T, Ghandi S, et al. Premorbid glycemic control modifies the interaction between acute hypoglycemia and mortality. Intensive Care Med. 2016;42:562-71.

60. Okazaki T, Hifumi T, Kawakita K, Shishido H, Ogawa D, Okauchi M, et al. Target serum sodium levels during intensive care unit management of aneurysmal subarachnoid hemorrhage. Shock. 2017;48:558-63.

61. Uozumi Y, Mizobe T, Miyamoto H, Ashida N, Katsube T, Tatsumi S, et al. Decreased serum sodium levels predict symptomatic vasospasm in patients with subarachnoid hemorrhage. J Clin Neurosci. 2017;46:118-23.
62. Mapa B, Taylor BE, Appelboom G, Bruce EM, Claassen J, Connolly ES Jr. Impact of hyponatremia on morbidity, mortality, and complications after aneurysmal subarachnoid hemorrhage: a systematic review. World Neurosurg. 2016:85:305-14.

63. Kao L, Al-Lawati Z, Vavao J, Steinberg GK, Katznelson L. Prevalence and clinical demographics of cerebral salt wasting in patients with aneurysmal subarachnoid hemorrhage. Pituitary. 2009;12:347-51.

64. Hannon MJ, Behan LA, O'Brien MM, Tormey W, Ball SG, Javadpour M, et al. Hyponatremia following mild/moderate subarachnoid hemorrhage is due to SIAD and glucocorticoid deficiency and not cerebral salt wasting. J Clin Endocrinol Metab. 2014;99:291-8.

65. Shah K, Turgeon RD, Gooderham PA, Ensom MHH. Prevention and treatment of hyponatremia in patients with subarachnoid hemorrhage: a systematic review. World Neurosurg. 2018;109:222-9.

66. Crompton MR. Hypothalamic lesions following the rupture of cerebral berry aneurysms. Brain. 1963;86:301-14.

67. Beseoglu K, Etminan N, Steiger HJ, Hanggi D. The relation of early hypernatremia with clinical outcome in patients suffering from aneurysmal subarachnoid hemorrhage. Clin Neurol Neurosurg. 2014;123:164-8.

68. Qureshi Al, Suri MF, Sung GY, Straw RN, Yahia AM, Saad M, et al. Prognostic significance of hypernatremia and hyponatremia among patients with aneurysmal subarachnoid hemorrhage. Neurosurgery. 2002;50:749-55.

69. Wartenberg KE, Schmidt JM, Claassen J, Temes RE, Frontera JA, Ostapkovich $\mathrm{N}$, et al. Impact of medical complications on outcome after subarachnoid hemorrhage. Crit Care Med. 2006;34:617-23.

70. Fisher LA, Ko N, Miss J, Tung PP, Kopelnik A, Banki NM, et al. Hypernatremia predicts adverse cardiovascular and neurological outcomes after SAH. Neurocrit Care. 2006;5:180-5.

71. Lantigua H, Ortega-Gutierrez S, Schmidt JM, Lee K, Badjatia N, Agarwal S, et al. Subarachnoid hemorrhage: who dies, and why? Crit Care. 2015;19:309.

72. Spatenkova V, Bradac O, de Lacy P, Skrabalek P, Suchomel P. Dysnatremia as a poor prognostic indicator in patients with acute subarachnoid hemorrhage. J Neurosurg Sci. 2017;61:371-9.

\section{Ready to submit your research? Choose BMC and benefit from:}

- fast, convenient online submission

- thorough peer review by experienced researchers in your field

- rapid publication on acceptance

- support for research data, including large and complex data types

- gold Open Access which fosters wider collaboration and increased citations

- maximum visibility for your research: over $100 \mathrm{M}$ website views per year

At BMC, research is always in progress.

Learn more biomedcentral.com/submissions 